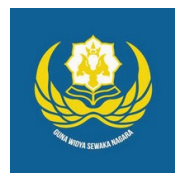

Jurnal Analogi Hukum

Journal Homepage: https://ejournal.warmadewa.ac.id/index.php/analogihukum

\title{
Karakteristik Perjanjian Jual Beli Tanah yang Belum Terdaftar Hak Atas Tanah
}

\author{
I Gusti Bagus Andika Bagaskara*, I Ketut Kasta Arya Wijaya dan Luh Putu Suryani \\ Fakultas Hukum, Universitas Warmadewa, Denpasar, Bali-Indonesia \\ *bagusandikabagaskara@gmail.com
}

How To Cite:

Bagaskara, I. G. B. A., Wijaya, I. K. K. A., \& Suryani, L. P. (2021). Karakteristik Perjanjian Jual Beli Tanah yang Belum Terdaftar Hak Atas Tanah. Jurnal Analogi Hukum. 3 (2). 256-260. Doi: https://doi.org/10.22225/ah.3.2.2021.256-260

\begin{abstract}
Government Regulation Number 24 of 1997 concerning Land Registration, the Government requires all of the land to register their land with the competent authority, but in society there are still lands that have not registered the phenomenon, so to ensure legal certainty for all overland. Then land that has not been registered must be registered. From the aspect of legal and procedural risks, it will be different from registered lands if the transfer of land rights is carried out. There are two problem formulations discussed in this paper 1. What are the characteristics of the sale and purchase agreement whose land has not been registered? 2. What is the legal certainty for the sale and purchase agreement of land rights that have not been registered? In writing this thesis using normative legal research, normative legal research requires legal materials including primary legal materials and secondary legal materials. The results from the study can be argued that the legal risk aspect is more prone to occur compared to land that has been registered, then from the procedural aspect are different from land that has been registered where the land was not registered requires precision so as not to cause legal problems.
\end{abstract}

Keywords: Characteristics; Legal Certainty; Land Rights .

\begin{abstract}
Abstrak-Peraturan pemerintah Nomor 24 Tahun 1997 tentang Pendaftaran Tanah, Pemerintah mewajibkan seluruh pemegang hak atas tanah untuk mendaftarkan tanahnya kepada instansi yang berwenang, namun di dalam masyarakat masih ada tanah-tanah yang belum terdaftar ada fenomena ini, maka untuk menjamin kepastian hukum terhadap pemegang hak atas tanah maka tanah yang belum terdaftar wajib didaftarkan. Dari aspek resiko hukum dan procedural akan berbeda dengan tanah-tanah yang sudah terdaftar jika dilakukan peralihan hak atas tanah. Ada dua rumusan masalah yang dibahas dalam penulisan ini adalah sebagai berikut 1 . Bagaimanakah karakteristik perjanjian jual beli yang tanahnya belum terdaftar ? 2. Bagaimanakah kepastian hukum terhadap perjanjian jual beli hak atas tanah yang belum terdaftar ? dalam penulisan skripsi ini mempergunakan penelitian hukum normatif, dalam penelitian hukum normatif memerlukan bahan-bahan hukum diantaranya adalah bahan hukum primer dan bahan hukum sekunder. Dari hasil penelitian dapat dikemukakan bahwa segi resiko hukum lebih rawan terjadi dibandingkan dengan tanah yang sudah terdaftar, kemudian dari aspek prosedural akan berbeda dengan tanah-tanah yang sudah terdaftar dimana tanah yang belum terdaftar memerlukan ketelitian agar tidak menimbulkan permasalahan hukum.
\end{abstract}

Kata Kunci: Karakteristik; Kepastian Hukum; Hak Atas Tanah

\section{Pendahuluan}

Sejak adanya UUPA, secara yuridis formal ada keinginan sangat kuat untuk memfungsikan hukum agraria nasional sebagai alat membawa kemakmuran, kebahagiaan dan keadilan bagi negara dan masyarakat tani dalam rangka masyarakat adil dan makmur yang diatur dalam Undang-Undang Nomor 5 Tahun 1960 atau biasa disebut UUPA secara ideologis mempunyai hubungan yang sangat erat dengan kaum petani Indonesia.

Sebagai capital asset, tanah telah tumbuh sebagai benda ekonomi yang sangat penting, tidak saja sebagai bahan perniagaan tapi juga sebagai objek spekulasi. Tanah memiliki arti penting dalam kehidupan manusia karena tanah mempunyai fungsi ganda. Sebagai social asset, tanah merupakan sarana pengikat kesatuan 
sosial dikalangan masyarakat Indonesia. Disatu sisi tanah harus dipergunakan dan dimanfaatkan sebesar- besarnya untuk kesejahteraan dan kemakmuran rakyat dan juga harus menjaga kelestariannya (Rubaie, 2007).

Setiap perbuatan yang dimaksudkan memindahkan Hak Milik atas tanah diatur dalam Peraturan Pemerintah. Hal ini diamanatkan dalam Pasal 26 Peraturan Dasar Pokok-pokok Agraria (UUPA). Ketentuan pendaftaran tanah di Indonesia diatur dalam UUPA Pasal 19 Jo Pasal 37 ayat (1) Peraturan Pemerintah Nomor 24 Tahun 1997 tentang Pendaftaran Tanah Peralihan hak atas tanah dan hak milik atas satuan rumah susun melalui jual beli, tukar menukar, hibah, pemasukan dalam perusahaan dan perbuatan hukum pemindahan hak lainnya, kecuali pemindahan hak melalui lelang hanya dapat didaftarkan jika dibuktikan dengan akta yang dibuat Pejabat Pembuat Akta Tanah (PPAT) yang berwenang menurut ketentuan peraturan perundang-undangan.

Menurut Pasal 19 ayat UUPA tentang Pendaftaran Tanah, pemerintah mengeluarkan Peraturan Pemerintah Nomor 10 Tahun 1961 tentang Pendaftaran Tanah. Berdasarkan Peraturan Pemerintah Nomor 10 Tahun 1961 tersebut hasilnya tidak sesuai dengan apa yang diharapkan oleh pemerintah. Dijelaskan pada Peraturan Pemerintah Nomor 24 Tahun 1997 tentang Pendaftaran Tanah yang berbunyi

Dalam kenyataannya pendaftaran tanah yang diselenggarakan berdasarkan Peraturan Pemerintah Nomor 10 Tahun 1961 tersebut selama lebih dari 35 tahun belum cukup memberikan hasil yang memuaskan, Sehubungan dengan itu maka dalam rangka meningkatkan dukungan yang lebih baik pada pembangunan nasional dengan memberikan kepastian hukum di bidang pertanahan, dipandang perlu untuk mengadakan penyempurnaan pada ketentuan yang mengatur pendaftaran tanah. Dalam Peraturan Pemerintah Nomor 24 Tahun 1997 yang dimaksud dengan pendaftaran tanah, disebut oleh Pasal 1 ayat (1)

Pendaftaran tanah adalah rangkaian kegiatan yang dilakukan oleh Pemerintah secara terus menerus, berkesinambungan dan teratur, meliputi pengumpulan, pengolahan, pembukuan, dan penyajian serta pemeliharaan data fisik dan data yuridis, dalam bentuk peta dan daftar, mengenai bidang-bidang tanah dan satuan- satuan rumah susun, termasuk pemberian surat tanda bukti haknya bagi bidang - bidang tanah yang sudah ada haknya dan hak milik atas satuan rumah susun serta hak-hak tertentu yang membebaninya.
Dalam Peraturan Pemerintah Nomor 24 Tahun 1997 tentang Pendaftaran Tanah yang menyempurnakan Peraturan Pemerintah Nomor 10 Tahun 1961 tentang Pendaftaran Tanah ini, tetap dipertahankan tujuan diselenggarakannya pendaftaran tanah sebagai hakikatnya sudah ditetapkan oleh Pasal 19 UUPA, bahwa pendaftaran tanah merupakan tugas pemerintah yang diselenggarakan dalam rangka menjamin kepastian hukum dibidang pertanahan.

Untuk menjamin kepastian hukum, ketertiban hukum dan memberikan perlindungan hukum bagi para pihak, maka perlu adanya kajian tentang jual beli tanah yang belum didaftarkan atau belum bersertipikat dengan kuasa menjual. Pemikiran secara teoritis kritis perlu dilakukan guna mengantisipasi dan mencegah terjadinya penyelundupan hukurri dalam praktek peralihan hak atas tanah dengan cara jual beli, utamanya hak atas tanah yang belum didaftarkan atau belum bersertipikat, sehingga jual beli hak atas tanah yang belum bersertipikat ada kepastian hukum tanpa adanya penyalahgunaan hukum.

Berdasarkan uraian pada latar belakang tersebut maka peneliti tertarik untuk meneliti terkait dengan karakteristik yang ada pada jual beli tanah yang belum terdaftar. Untuk itu Peneliti akan mengambil Judul yaitu KARAKTERISTIK PERJANJIAN JUAL BELI TANAH YANG BELUM TERDAFTAR HAK ATAS TANAHNYA'

Berdasarkan pernyataan diatas, berikut rumusan masalah yang ditemukan yaitu; Bagaimanakah karakteristik perjanjian jual beli tanah yang belum terdaftar hak atas tanahnya? 2. Bagaimana kepastian hukum terhadap perjanjian jual beli yang tanahnya belum terdaftar?

Adapun yang menjadi tujuan dalam penelitian ini diantaranya yaitu Untuk mengetahui dan mengkaji karakteristik perjanjian jual beli yang tanahnya belum terdaftar dan untuk mengetahui dan mendeskripsikan tentang kepastian hukum terkait perjanjian jual beli yang tanahnya belum terdaftar.

\section{Metode}

Tipe penelitian yang digunakan dalam penelitian ini adalah jenis penelitian hukum normatif. Pendekatan masalah yang digunakan yaitu pendekatan secara perundang-undangan yaitu pendekatan yang dilakukan dengan menggunakan semua peraturan perundangundangan yang termasuk dalam permasalahan 
yang dihadapi. Sedangkan bahan hukum yang dipergunakan adalah bahan hukum primer dan bahan hukum sekunder. Selanjutnya teknik pengumpulan bahan hukum dilakukan dengan cara melakukan klasifikasi terhadap bahanbahan hukum melakukan pencatatan seluruh bahan hukum membaca serta melakukan sistematika terhadap bahan-bahan hukum yang telah terkumpul, yang berkaitan dengan permasalahan dalam penelitian ilmiah proposal ini yang berkenaan dengan pelaksanaan jual beli tanah yang belum terdaftar sedangkan bahan hukum yang terkumpul dengan cara mencatat dan menganalisa. Penyajian ini dilakukan secara deskriptif analisis yang dilakukan dengan cara menyusun kalimat secara sistematis untuk mendapatkan simpulan yang baik dan benar secara logis dan ilmiah.

\section{Hasil dan Pembahasan}

\section{Karateristik Pendaftaran Akta Jual Beli Hak Atas Tanah yang Belum Bersertipikat}

Dalam Pasal 37 Peraturan Pemerintah Nomor 24 Tahun 1997 yang mengatur tentang jual beli hak atas tanah yang belum bersertipikat. Terhadap jual beli hak atas tanah yang dilakukan sebelum berlakunya PP Nomor 24 Tahun 1997, maka bukti peralihan hak atas tanah yang berupa akta di bawah tangan yang dibuat oleh pihak penjual dan pembeli yang diketahui atau dikuatkan oleh Kepala Desa/ Lurah disertai bukti-bukti kepemilikan hak atas tanah lainnya diajukan kepada Kantor Pertanahan untuk didaftarkan pertama kalinya.

Dokumen yang harus diserahkan kepada Kantor Pertanahan untuk keperluan pendaftaran hak adalah:

1. Permohonan pendaftaran tanah secara sporadik, dengan mengisi formulir (Model A) yang disediakan oleh Kantor Pertanahan.

2. Foto copy Kartu Tanda Penduduk pemohon dan/atau kuasanya yang masih berlaku

3. Foto copy Kartu Susunan Keluarga (KSK/KK) dari pemohon yang masih berlaku.

4. Bukti pelunasan Pajak Bumi dan Bangunan tahun terakhir.

5. Surat penguasaan penguasaan fisik bidang tanah yang ditandatangani oleh pemohon, dua orang saksi dan Kepala Desa/ Lurah.

6. Keterangan Kutipan Register Letter C sebagai tanda pendaftaran sementara tanah hak milik Indonesia, yang dibuat oleh Kepala Desa/ Lurah.

7. Surat Keterangan Riwayat Tanah yang dibuat oleh Kepala Desa/Lurah.

8. Bukti perolehan tanah. Apabila tanah diperoleh melalui jual beli sebelum berlakunya PP Nomor 24 Tahun 1997 maka buktinya berupa akta jual beli yang dibuat oleh para pihak dengan diketahui Kepala Desa/Lurah. Sedangkan jika hak atas tanah diperoleh melalui jual beli setelah berlakunya PP Nomor 24 Tahun 1997, maka buktinya harus berupa akta jual beli-yang dibuat oleh PPAT

Setelah semua dokumen tersebut lengkap maka dilakukan tahapan prosedur pendaftaran tanah secara sporadis sebagai berikut

1. Mengajukan permohonan pendaftaran tanah secara sporadis kepada Kepala Kantor Pertanahan.

2. Membayar biaya pendaftaran. Biaya pendaftaran ini telah ditetapkan dalam Peraturan Pemerintah Nomor 46 Tahun 2002.

3. Setelah dilakukan pembayaran biaya pendaftaran, maka kemudian dilakukan pengukuran tanah oleh petugas ukur dari Kantor Pertanahan.

4. Pengumpulan dan penelitian data yuridis bidang tanah dan penetapan batas.

5. Pengumuman data fisik dan data yuridis serta pengesahannya. Pengumuman dilakukan dalam waktu selama 60 hari, setelah jangka. waktu pengumuman berakhir maka kemudian dilakukan pengesahan oleh Kepala Kantor Pertanahan.

6. Pembukuan Hak, setelah dilakukan pengakuan dan pengesahan hak pasca diumumkan, maka kemudian dibuat buku tanah hak atas tanah tersebut yang ditandatangani oleh Kepala Kantor Pertanahan.

7. Penerbitan sertipikat, yang dilakukan setelah dibuatkan buku tanah hak atas tanah bersangkutan, di mana kutipan data yuridis dan data fisik tanah yang tercantum dalam buku tanah kemudian ditulis dalam sertipikat hak atas tanah tersebut.

8. Penyerahan sertipikat, yang dilakukan setelah sertipikat selesai dibuat dan ditandatangani oleh Kepala Kantor Pertanahan.

Setelah dibuatkan Buku Tanah, maka diterbitkan sertipikat hak atas tanah yang berisi kutipan data fisik dan data yuridis serta 
dilampiri gambar situasi. sertipikat hak atas tanah atas nama pemegang hak (pemohon pendaftaran hak atas tanah) tersebut ditandatangani oleh Kepala Kantor Pertanahan. Setelah sertipikat ditandatangani maka kemudian diserahkan kepada pemegang hak. Apabila pengurusan pendaftaran jual beli hak atas tanah tersebut dilakukan orang lain, maka harus disertai dengan surat kuasa khusus yang diberikan oleh pemegang hak kepada kuasanya, surat kuasa mana dipergunakan untuk mengurus seluruh proses pendaftaran hak untuk pertama kali sampai penerimaan sertipikat tanah pada saat proses pendaftaran haknya telah selesai.

Berdasarkan pada uraian diatas maka dapat disimpulkan bahwa ada beberapa karakteristik dari Pendaftaran Akta Jual Beli Hak atas Tanah yang Belum Bersertipikat, adalah dari resiko jual beli tanah yang belum bersertipikat mempunyai resiko hukum yang lebih besar, hal ini dikarenakan diperlukan pembuktian yang lebih lengkap. Dari aspek prosedur jual beli hak atas tanah yang belum didaftarkan juga berbeda dengan tanah yang telah didaftarkan atau yang memiliki. sertipikat. Jual beli tanah yang tidak dibuat dengan akta jual beli yang dibuat oleh PPAT, maka proses jual beli tersebut harus diulang dengan akta jual beli yang dibuat oleh PPAT. Hal ini untuk memenuhi syarat dan ketentuan agar peralihan hak atas tanah tersebut dapat didaftarkan dengan mendasarkan pada PP Nomor 24 Tahun 1997.

\section{Kepastian Hukum Perjanjian Jual Beli Tanah yang Belum Terdaftar}

Kepastian hukum mengandung dua pengertian, yaitu pertama, adanya aturan yang bersifat umum membuat individu mengetahui perbuatan apa yang boleh atau tidak boleh dilakukan, dan kedua, berupa keamanan hukum bagi individu dari kesewenangan pemerintah karena dengan adanya aturan yang bersifat umum itu individu dapat mengetahui apa saja yang boleh dibebankan atau dilakukan oleh Negara terhadap individu (Lubis \& Lubis, 2010).

Jual beli tanah pada dasarnya merupakan salah satu pengalihan hak atas tanah kepada pihak lain yaitu dari penjual kepada pembeli dengan sejumlah pembayaran, menurut pasal 1457 KUH Perdata, pengertian jual beli yaitu, suatu perjanjian dengan mana pihak yang satu mengikatkan dirinya untuk menyerahkan sesuatu hak milik atas sesuatu barang dan pihak lain untuk membayar harga yang telah dijanjikan (Tjitrosudibio, 1992).
Kepastian hukum mengenai hak atas tanah tercantum dalam ketentuan Pasal 19 ayat (1) UUPA, yang berbunyi Untuk menjamin kepastian hukum oleh Pemerintah diadakan pendaftaran tanah di seluruh wilayah Republik Indonesia menurut ketentuan ketentuan yang diatur dengan Peraturan Pemerintah. Pasal 19 ayat (1) UUPA tersebut ditujukan kepada Pemerintah sebagai suatu instruksi agar di seluruh wilayah Indonesia diadakan pendaftaran tanah yang sifatnya recht kadaster artinya yang bertujuan menjamin kepastian hokum (Husni, 2009). Sedangkan untuk mewujudkan kepastian hukum diperlukan pelaksanaan dari hukum itu sendiri.

Jaminan kepastian hukum hak atas tanah dapat diperoleh bagi pemegang hak dengan wajib dilakukan inventarisasi data-data yang berkenaan dengan setiap peralihannya (Lubis \& Lubis, 2009). Terselenggaranya pendaftaran tanah secara baik merupakan dasar dan perwujudan tertib administrasi di bidang pertanahan. Untuk mencapai tertib administrasi tersebut setiap bidang tanah dan satuan rumah susun, termasuk peralihan, pembebanan dan hapusnya wajib didaftar.

Tujuan pendaftaran tanah adalah untuk memberikan kepastian hukum dan perlindungan hukum kepada pemegang hak atas tanah. Yang dilindungi dengan diadakannya pendaftaran tanah yaitu pemegang sertipikat hak atas tanah, karena dengan dilakukannya pendaftaran tanah berarti akan tercipta kepastian hukum, kepastian hak serta tertib administrasi pertanahan sehingga semua pihak terlidungi dengan baik, baik pemegang sertipikat, pemegang hak atas tanah, pihak ketiga yang memperoleh hak atas tanah maupun pemerintah sebagai penyelenggara Negara.

Salah satu tujuan pendaftaran tanah sebagaimana ditetapkan dalam pasal 3 Peraturan Pemerintah No.24 Tahun 1997 adalah untuk memberikan jaminan kepastian hukum dan perlindungan hukum kepada pemegang hak atas suatu bidang tanah,satuan rumah susun, dan hak-hak lain yang terdaftar agar dengan mudah membuktikan dirinya sebagai pemegang hak yang bersangkutan. Kepemilikan tanah mengandung dua aspek pembuktian agar kepemilikan tersebut dapat dikatakan kuat dan sempurna yaitu (Nae, 2013):

Bukti surat yang didalamnya terdapat 4 hal pokok yang wajib dipenuhi dalam penerbitan sertipikat hak atas tanah yaitu;

(1) status dan dasar hukum. Hal ini untuk mengetahui dan memastikan dengan dasar apa 
tanah diperoleh.

(2) Identitas pemegang hak atau yang dikenal dengan kepastian.

Kepastian hukum jual beli tanah yang belum terdaftar sebagaimana ditegaskan dalam Pasal 19 dan pasal 23 UUPA dan Pasal 32 ayat (2) PP 24 Tahun 1997 sepanjang data fisik dan data yuridis yang tercantum dalam sertipikat adalah data yang benar maka dapat dilanjutkan dengan pendaftaran tanah pertama kali atau yang belum terdaftar, bahwa akhir dari proses pendaftaran tanah adalah pemberian surat-surat tanda bukti hak yang umum disebut sertipikat sebagai alat bukti hak yang kuat. Jaminan kekuatan dan kepastian hukum sertipikat yang diterbitkan melalui pengakuan hak sama dengan sertipikat yang diterbitkan melalui konversi maupun penegasan, dan tidak dapat dibuktikan sebaliknya. Dengan demikian bahwa kepastian hukum dari tanah yang belum terdaftar yang dilanjutkan pembuatan akta jual beli di PPAT sama kekuatan pembuktiannya dengan jual beli tanah yang telah terdaftar.

\section{Simpulan}

Berdasarkan pada uraian pembahasan skripsi ini sebelumnya dapat disimpulkan sebagai berikut

1. Karakteristik dari perjanjian jual beli yang tanahnya belum bersertipikat adalah dari resiko jual beli tanah yang belum bersertipikat mempunyai resiko hukum yang lebih besar, hal ini dikarenakan diperlukan pembuktian yang lebih lengkap, bagi tanah yang belum didaftarkan hak kepemilikannya atau belum bersertipikat, memiliki resiko hukum dan kerawanan yang lebih tinggi jika dilakukan peralihan hak melalui jual beli.

2. Kepastian hukum jual beli tanah yang belum terdaftar sebagaimana ditegaskan dalam Pasal 19 dan pasal 23 UUPA dan Pasal 32 ayat (2) PP 24 Tahun 1997 sepanjang data fisik dan data yuridis yang tercantum dalam sertipikat adalah data yang benar maka dapat dilanjutkan dengan pendaftaran tanah pertama kali atau yang belum terdaftar, bahwa akhir dari proses pendaftaran tanah adalah pemberian surat- surat tanda bukti hak yang umum disebut sertipikat sebagai alat bukti hak yang kuat. Jaminan kekuatan dan kepastian hukum sertipikat yang diterbitkan melalui pengakuan hak sama dengan sertipikat yang diterbitkan melalui konversi maupun penegasan, dan tidak dapat dibuktikan sebaliknya.

Pemerintah dalam hal ini Badan Pertanahan Nasional (BPN) harus meningkatkan pelaksanaan pendaftaran tanah yang belum terdaftar secara sistematik terutama untuk masyarakat menengah kebawah yang tanahnya belum terdaftar untuk mendapatkan jaminan kepastian hukum.

Masyarakat yang tanahnya belum terdaftar sepatutnya untuk mendaftarkan tanahnya untuk mendapatkan jaminan kepastian hukum, agar tidak terjadi permasalahan hukum di kemudian hari.

\section{Daftar Pustaka}

Husni, T. (2009). Pembuatan Akta Pertanahan oleh Notaris. Yogyakarta: LaksBang PRESSindo.

Lubis, Y., \& Lubis, R. (2010). Hukum Pendaftaran Tanah. Bandung: Mandar Maju.

Nae, F. E. (2013). Kepastian Hukum Terhadap Hak Milik Atas Tanah Yang Sudah Bersertifikat. Lex Privatum. 1(5). Retrieved from https:// ejournal.unsrat.ac.id/index.php/ lexprivatum/article/view/3079

Rubaie, A. (2007). Hukum Pengadaan Tanah Untuk Kepentingan Umum. Malang: Bayumedia.

Tjitrosudibio, S, (1992), Kitab Undang-Undang Hukum Perdata. Jakarta: PT. Pratnya Paramita. 